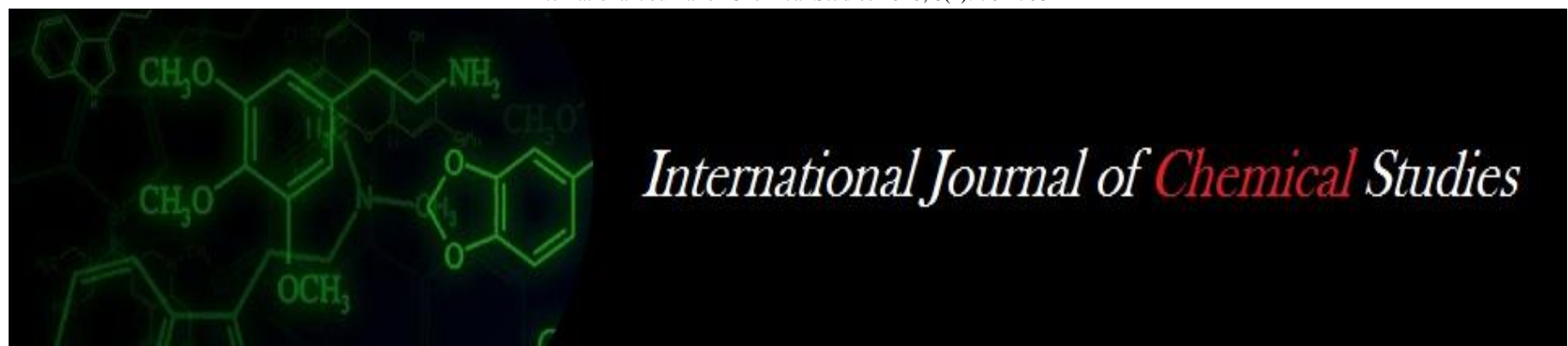

P-ISSN: 2349-8528

E-ISSN: 2321-4902

IJCS 2020; 8(1): 764-768

(C) 2020 IJCS

Received: 22-11-2019

Accepted: 24-12-2019

Mukesh Kumar

Scientist, Irrigation and

Drainage Engineering Division,

ICAR-CIAE, Bhopal, Madhya

Pradesh, India

\section{A Sarangi}

Principal Scientist, Water

Technology Centre, ICAR-IARI,

New Delhi, India

\section{DK Singh}

Principal Scientist, Water

Technology Centre, ICAR-IARI,

New Delhi, India

\section{S Sudhishri}

Principal Scientist, Water

Technology Centre, ICAR-IARI,

New Delhi, India

\section{AR Rao}

Principal Scientist, ICAR-

IASRI, New Delhi, India

\section{Manoj Kumar}

Scientist, Agricultural

Mechanization Division, ICARCIAE, Bhopal, Madhya Pradesh, India

\section{Water productivity of wheat cultivars under saline irrigation and foliar potassium fertigation}

\author{
Mukesh Kumar, A Sarangi, DK Singh, S Sudhishri, AR Rao and Manoj \\ Kumar
}

DOI: https://doi.org/10.22271/chemi.2020.v8.i1k.8358

\begin{abstract}
Availability of fresh water is one of the limiting factors affecting the growth and yield of a variety of crops. Besides this, declining water table depths and deterioration of its quality is rampant in many parts of the world today. Salt-affected irrigated land in the world is increasing over the years. Sustaining crop growth and yield with proper management of irrigation water under saline environment necessitates modification in the conventional crop cultivation practices. A field experiment was conducted on two winter wheat (Triticum aestivum L.) cultivars (viz. salt tolerant cultivar KRL-1-4 and salt non-tolerant cultivar HD-2894) under saline irrigation regimes $\left(1.7\right.$ to $\left.12 \mathrm{dSm}^{-1}\right)$ with and without foliar potassium fertigation in the research farm of the Water Technology Center (WTC), ICAR-IARI, New Delhi, India. In this experiment potassium was applied in the ratio of $\mathrm{K}^{+}: \mathrm{Na}^{+}(1: 10)$ as foliar application during the heading stage of the crop. The KRL-1-4 cultivar under foliar treatment resulted in increase in water productivity by 6.3 to $21.1 \%$ as compared to the non-foliar treatments with irrigation water salinity ranging from 1.7 to $12 \mathrm{dSm}^{-1}$. The increase in water productivity of wheat with foliar potassium fertigation over the non-foliar application for the HD 2894 cultivar was found to vary from 3.8 to $14.9 \%$ with irrigation water salinity upto $12 \mathrm{dSm}^{-1}$. Overall, it was observed that the water productivity of both cultivars under foliar potassium fertigation resulted in higher water productivity for all salinity regimes as compared to the non-foliar treatment.
\end{abstract}

Keywords: Wheat yield, salt-tolerant cultivar, saline irrigation, foliar potassium fertigation

\section{Introduction}

Water is one of the major inputs in crop production. In the present scenario of water scarcity, the availability of water for crop production is diminishing day by day due to increasing share of water for domestic and industrial sectors. Also, pollution is another major threat of water availability. Enhancing water productivity of any crop or cropping system is an important indicator of judicious water management in crop production and productivity.

Suitability of water resources for crop production depends upon the crop and its variety type. Irrigation with poor quality water deteriorates soil properties and creates conditions unfavorable for growth of crops under normal farming practices. The most common problems resulting from irrigation with poor quality water can be grouped into three categories viz., stress due to salinity, alkalinity and toxicity hazards. Salinity is one of the important factors which need to be properly managed. Amount and kind of salts in irrigation water determine the stress which hinders growth of crop. Salt-affected irrigated land in the world and in India is about $20 \%$ and $17 \%$ of total irrigated land, respectively (Ghassemi et al., 1995) ${ }^{[3]}$. Moreover, $0.2-0.4 \%$ of the total arable land every year is going out of cultivation because of salinity and water logging problem (Jabeen and Ahmad, 2012) ${ }^{[4]}$.

Wheat cultivation under irrigated saline environment requires judicious application of different nutrients besides agricultural water management. The foliar application of nutrients on the crop is getting widely accepted nowadays. Many researchers have shown the direct benefits of applying nutrients in the form of foliar on the crop in terms of increase in growth and yield of the crop. The supply of water and nutrients to the crops in saline irrigation environment is restricted which affects the growth and yield of the crop with low water productivity. It is desirable to obtain the high grain yield at lesser amount of water to save the recourses.
Corresponding Author Mukesh Kumar

Scientist, Irrigation and Drainage Engineering Division, ICAR-CIAE, Bhopal, Madhya Pradesh, India 
Baque et al. (2006) ${ }^{[2]}$ investigated the effect of potassium fertilizer on wheat by conducting pot experiment under greenhouse condition. The aim was to investigate whether potassium could improve the water stress tolerance in terms of growth, yield and nutrient uptake by plants. Adiloglu et al. (2007) ${ }^{[1]}$ also conducted pot experiment under greenhouse conditions and the objective was to determine the effects of different levels of $\mathrm{NaCl}$ and $\mathrm{KCl}$ salts (viz. 0, 15, 30 and 60 $\mathrm{mM})$. Zheng et al. (2008) ${ }^{[9]}$ conducted an experiment to answer the question whether the exogenous $\mathrm{KNO}_{3}$ can alleviate adverse effects of salt stress in winter wheat or not? Monitoring of plant growth, $\mathrm{K}^{+} / \mathrm{Na}^{+}$accumulation and the activity of some antioxidant enzymes were undertaken during the experiment. Mesbah (2009) ${ }^{[6]}$ conducted field experiment to study the effect of saline irrigation regimes and foliar spraying of potassium with varying doses as 1, 2 and $3 \%$ besides the control on yield, plant growth and yield component and water productivity of wheat crop. Russo et al. (2009) ${ }^{[8]}$ investigated the response of lysimeter grown wheat under rainfed condition to various levels of soil salinity. Raza et al. (2013) [7] conducted experiment to evaluate the physiological and nutrient uptake of two wheat cultivars (i.e. Lasani-2008 and Auqab-2000) to foliar application of 1\% potassium $(\mathrm{K})$ at three different growth stages (viz. tillering, flower initiation and grain filling) which was investigated under water limited environment.

It is imperative to enhance the water productivity of crop under irrigated saline environment for sustainable crop production under deterioration of water and land due to various anthropogenic activities. Adoption of salt tolerant wheat cultivars along with salinity mitigation techniques would further facilitate the use of saline waters for irrigating wheat and would increase area under irrigation with poor quality water.

\section{Material and Methods \\ Site description}

Experiment was under taken in the research farm of Water Technology Centre, ICAR-Indian Agricultural Research Institute (IARI), New Delhi. The experiment was conducted for two years period during Rabi season of 2011-12 and 201213.WTC research farm is situated between $77^{\circ} 09^{\prime} 36^{\prime}$ ' $\mathrm{E}$ longitude and $28^{\circ} 37^{\prime} 55^{\prime}$ ' $\mathrm{N}$ latitude at an average elevation of $230 \mathrm{~m}$ above MSL (mean sea level). The climate of this area falls under the agro-climate zone of "Trans-Gangetic plains". The temperature of the summer months (i.e. May and June) is the maximum with temperature varying from $40{ }^{\circ} \mathrm{C}$ to $46{ }^{\circ} \mathrm{C}$. The temperature during winter months reach its lowest during January with minimum temperature ranging between $3{ }^{\circ} \mathrm{C}$ to $7{ }^{\circ} \mathrm{C}$ and sporadically reach below $0{ }^{\circ} \mathrm{C}$. The minimum temperature increases gradually from February till June which gets reduced only after the advent of south-west monsoon rain. Average annual rainfall of Delhi is about 750 $\mathrm{mm}$ and $80 \%$ of which occurs during three active south-west monsoon months viz. July, August and September. The wettest months in a year are July and August of every year. The rainfall during September to February have varying depths, intensity and duration which is mainly caused by western disturbances and due to retreating north-east monsoon. Average wind speed varies from a minimum of 3.5 $\mathrm{km} \mathrm{hr}^{-1}$ during October to $6.5 \mathrm{~km} \mathrm{hr}^{-1}$ during April. The experimental farm was equipped with surface irrigation facility having an overhead tank to store and prepare artificial saline water of different salinity levels for subsequent irrigation to different experimental plots.

\section{Experimental Details}

Field experiment was laid out in split-split plot design with four main plots and three replications. Four main plots were irrigated with one control and three different salinity levels [i.e. $\mathrm{S}_{1}\left(1.7 \mathrm{dSm}^{-1}\right.$, ground water salinity; control $): \mathrm{S}_{2}(4 \mathrm{dSm}-$ $\left.{ }^{1}\right)$ : $\mathrm{S}_{3}\left(8 \mathrm{dSm}^{-1}\right)$ and $\left.\mathrm{S}_{4}\left(12 \mathrm{dSm}^{-1}\right)\right]$. Each main plot was further divided into two sub-plots for foliar potassium $\left(\mathrm{F}_{1}\right)$ and nonfoliar potassium $\left(\mathrm{F}_{0}\right)$ treatments on both wheat cultivars. Further, each sub-plot was again divided into two sub-subplots to accommodate two different wheat cultivars such as salt tolerant cultivar $\mathrm{V}_{1}$ (KRL-1-4) and salt non-tolerant cultivarV $\mathrm{V}_{2}$ (HD 2894). The size of the main plot was $9 \mathrm{~m} \times 5 \mathrm{~m}$ and the spacing between two main plots was $3 \mathrm{~m}$. The spacing between two sub-plots was $1.5 \mathrm{~m}$ within the main plot (Fig. 1).

Different levels of saline irrigation water was prepared artificially by mixing three different salts viz. $\mathrm{NaCl}, \mathrm{MgSO}_{4}$, $\mathrm{CaCl}_{2}$ in the ratio 2.5: 1.5: 1 , respectively using the ground water available for irrigation in the farm. Foliar potassium in the ratio of $\mathrm{K}^{+}: \mathrm{Na}^{+}$as $1: 10$ was applied during the heading stage of the crop for three consecutive days to all different levels of salinity (Zheng et al., 2010) ${ }^{[10]}$. The potassium concentration during foliar application was kept at $1 \%$ level. The saline water was prepared in the overhead tank using the estimated quantity of three salts and surface irrigation was applied through portable pipe line system laid in the experiment. Before delivery of irrigation water to a given plot of desired salinity level, the available ground water having EC of $1.7 \mathrm{dSm}^{-1}$ was thoroughly mixed in the overhead tank and tested by EC meter to confirm salinity at different saline irrigation regimes viz. 4, 8 and $12 \mathrm{dSm}^{-1}$. Besides this, the measured quantity of irrigation water based on soil moisture deficit was applied to each plot under different treatments and the procedure was repeated for providing saline irrigation water in both years of experiment.

The irrigation water quality for salinity was measured before actual application of water to the crop at each irrigation using electrical conductivity (EC) meter. Quantity of irrigation water on volume basis applied to each treatment was estimated using the equation given below

$V(l)=\mathrm{PA} \times \frac{\mathrm{FC}-\mathrm{MC}_{\mathrm{bi}}}{100} \times \mathrm{BD} \times \mathrm{RZD} \times 1000$

Where, $\mathrm{V}(l)$ : volume of water in litre; FC: field capacity $(\%)$; $\mathrm{MC}_{\mathrm{bi}}$ : moisture content before irrigation (\%); $\mathrm{BD}$ : bulk density (gm/cc); RZD: root zone depth (m); PA: plot area $\left(\mathrm{m}^{2}\right)$.

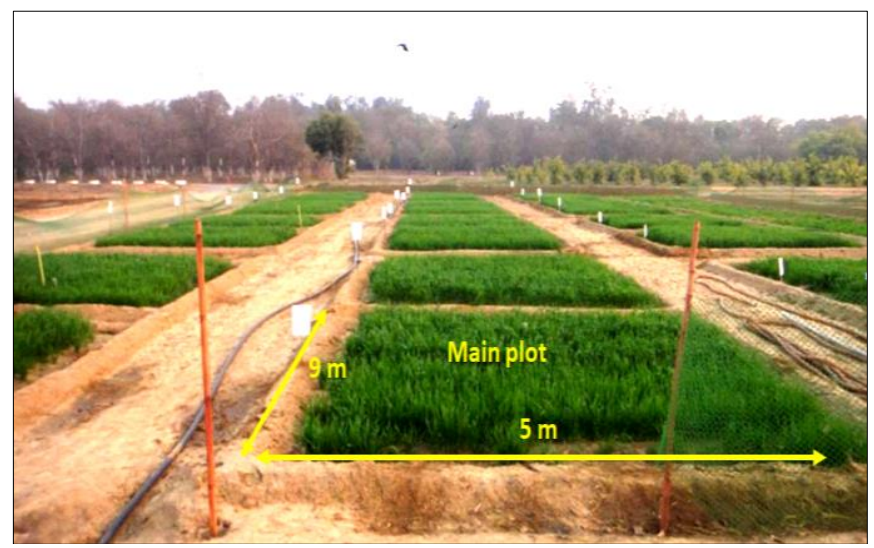

Fig 1: View of the experiment on 51 days after sowing (DAS) of wheat cultivars (Rabi 2012-13) 


\section{Scheduling of Irrigation in the Experiment}

The irrigation scheduling with saline water was carried out in the experiment using the soil moisture deficit criterion. The salinity, depths of irrigation and its data of application in days after sowing (DAS) and the total salt $(\mathrm{NaCl})$ added during two years of experiment (rabi2011-12 and 2012-13) is presented in Table 1. It was observed from Table 1 that the total irrigation water applied was $270 \mathrm{~mm}$ and $182 \mathrm{~mm}$ during Rabi 2011-12 and 2012-13, respectively. Application of less irrigation water may be attributable to occurrence of higher rainfall (131 mm) during Rabi 2012-13 as compared to 22 mm rainfall depth during Rabi 2011-12.

Table 1: Irrigation scheduling of saline water and the total salt $(\mathrm{NaCl})$ added under different treatments during two years of experiment

\begin{tabular}{|c|c|c|c|c|c|c|}
\hline DAS & $\begin{array}{c}\text { Irrigation } \\
\text { depth (mm) }\end{array}$ & DAS & $\begin{array}{c}\text { Irrigation } \\
\text { depth (mm) }\end{array}$ & $\begin{array}{l}\text { Salinity } \\
\left.\mathbf{d S m}^{-1}\right)\end{array}$ & $\begin{array}{c}\text { Total salt (NaCl) } \\
\text { added (t ha- }\end{array}$ \\
\hline \multicolumn{2}{|c|}{ Rabi 2011-12 } & \multicolumn{2}{|c|}{ Rabi $\mathbf{2 0 1 2 - 1 3}$} & & $\begin{array}{c}\text { Rabi } \\
\mathbf{2 0 1 1 - 1 2}\end{array}$ & $\mathbf{2 0 1 2 - 1 3}$ \\
\hline 17 & 25 & 18 & 22 & 1.7 & 1.47 & 0.99 \\
\hline 45 & 34 & 30 & 27 & 4 & 1.99 & 1.34 \\
\hline 65 & 61 & 74 & 32 & 8 & 5.44 & 3.67 \\
\hline 84 & 69 & 98 & 101 & 12 & 8.90 & 6.00 \\
\hline 106 & 81 & - & - & - & - & - \\
\hline
\end{tabular}

The foliar potassium fertigation protocol to increase the productivity of wheat cultivars under irrigated saline environment was standardized using the experiment generated data (Kumar et al., 2016).

\section{Water Productivity}

Water productivity (WP) is indicated by the yield per unit of water used during the crop growth period. WP is determined by dividing the marketable grain yield of crop by the water used to meet the crop evapotranspiration requirement and other losses. Water productivity is the ratio of two terms viz. the grain yield in the numerator and the water used in the denominator of the ratio.

Water productivity,

$$
\mathrm{WP}=\frac{\text { GrainYield }\left(\mathrm{kgha}^{-1}\right)}{\text { Water used }(\mathrm{mm})}
$$

\section{Results and Discussion}

Increase in Grain Yield of Wheat Cultivars Under Different Treatments

The grain yield of wheat cultivars treated with potassium $\left(\mathrm{K}_{2} \mathrm{SO}_{4}\right)$ foliar application under saline irrigation regimes for Rabi 2011-2012 are presented in Fig. 2. The KRL-1-4 cultivar under foliar treatment resulted in increase of grain yield by 6.5 to $22 \%$ as compared to the non-foliar treatments with irrigation water salinity ranging from 1.7 to $12 \mathrm{dSm}^{-1}$. The increase in grain yield of wheat with foliar potassium fertigation over the non-foliar treatment for the non-salt tolerant cultivar HD 2894 was found to be varying from 3 to $15 \%$ for salinity regimes of 1.7 to $12 \mathrm{dSm}^{-1}$. Moreover, under the same treatment combinations, the grain yield of both cultivars under irrigated saline regimes for Rabi 2012-13 are presented in Fig. 3.

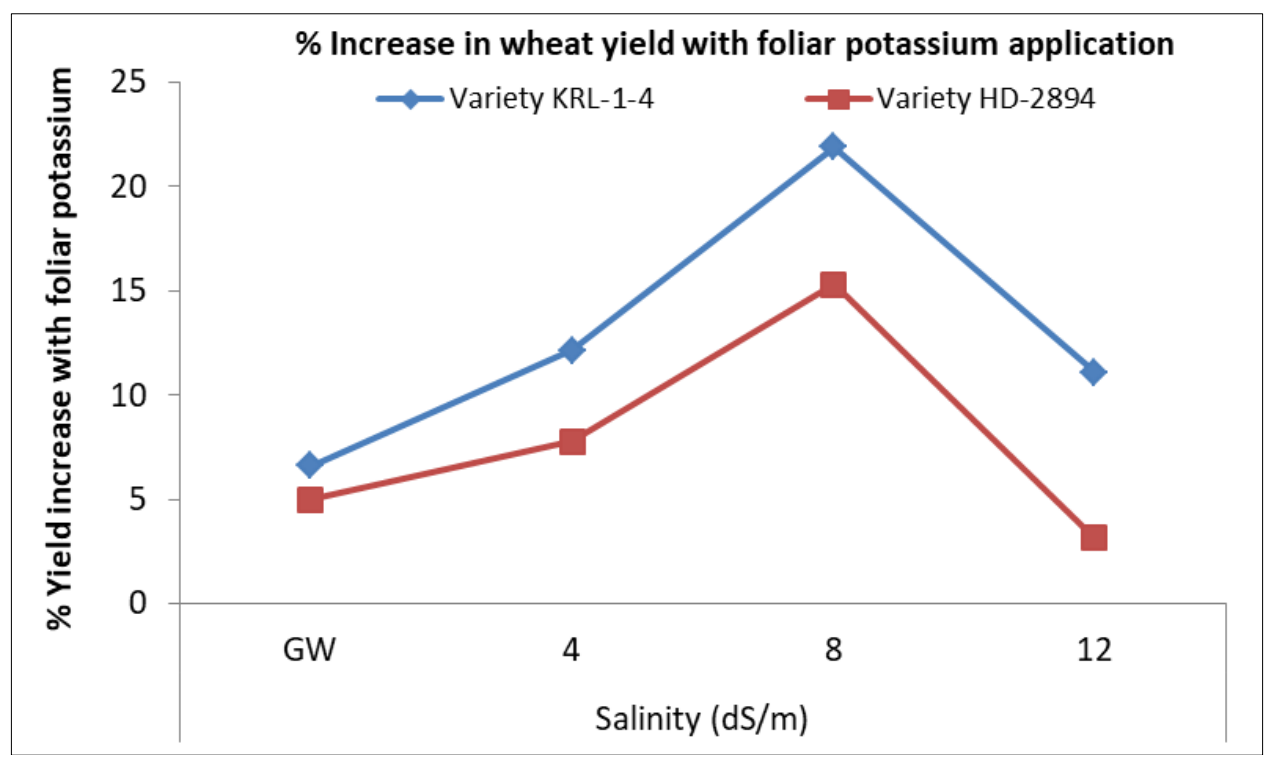

Fig 2: Percentage increase in grain yield of wheat cultivars with and without foliar potassium fertigation under irrigated saline regimes during Rabi 2011-2012

Nonetheless, the foliar potassium fertigation resulted in enhancing the grain yield of KRL-1-4 cultivar by $4.5 \%$ to $20 \%$ as compared to the control under all salinity levels. Whereas, for the HD 2894 cultivar, the increased yield due to foliar potassium fertigation varied from 2 to $14 \%$ as compared to the non-foliar treatment. However, the trend of increase in grain yield for Rabi 2012-13 was in line with the results of Rabi 2011-12. 


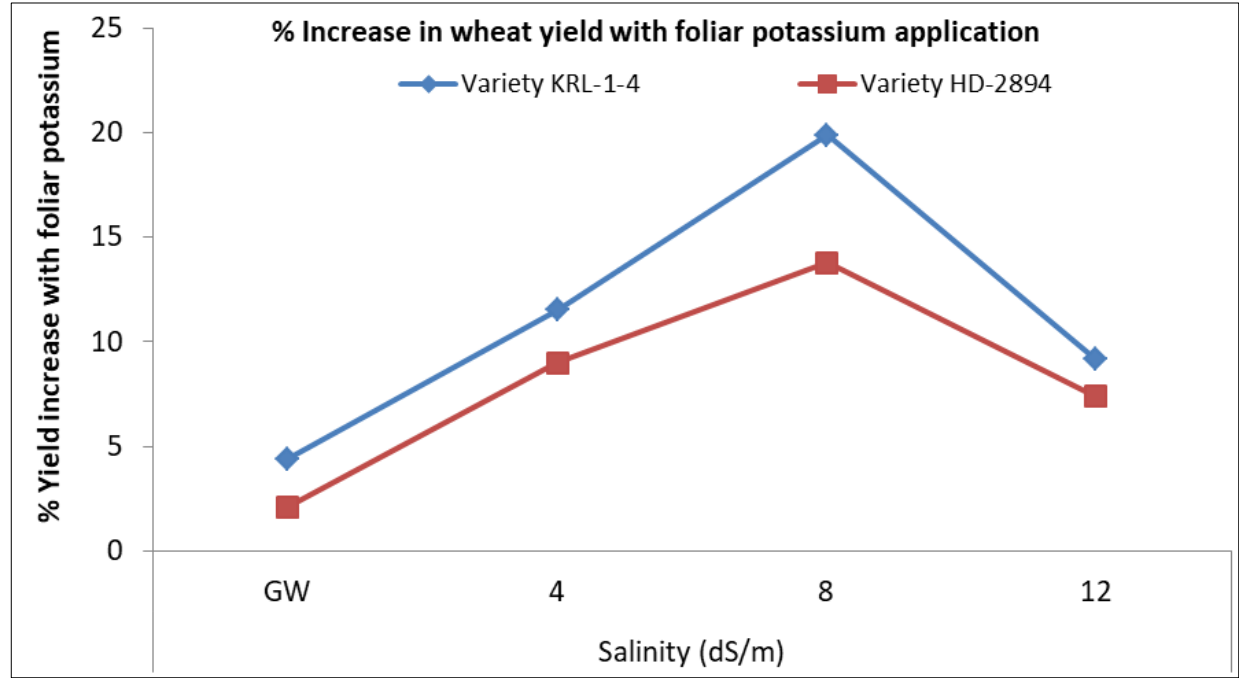

Fig 3: Percentage increase in grain yield of wheat cultivars with and without foliar potassium fertigation under irrigated saline regimes during Rabi 2012-2013

Overall, it was observed that the grain yield of both cultivars showed increase in the grain yield due to foliar potassium application. However, the effect of salinity on yield reduction of salt non-tolerant cultivar was more pronounced at salinity level of $4 \mathrm{dSm}^{-1}$ and above. Also, the percent increase of grain yield due to foliar potassium at salinity level of 4 and $8 \mathrm{dSm}^{-1}$ was observed to be higher than that at salinity regimes of 1.7 and $12 \mathrm{dSm}^{-1}$.

Water productivity of wheat cultivars with non-foliar and foliar potassium fertigation under different irrigation water salinity regimes

The water productivity of wheat cultivars treated with potassium foliar and non-foliar application under saline irrigation regimes for rabi 2011-2012 are presented in Fig. 4. It was observed from the figure that KRL-1-4 cultivar treated with foliar potassium resulted in the water productivity of $1.68,1.61,1.55$ and $1.22 \mathrm{kgm}^{-3}$ for the salinity levels of 1.7 ,
$4,8,12 \mathrm{dSm}^{-1}$, respectively. The water productivity of KRL1-4 without foliar potassium fertigation was found to be 1.58, $1.44,1.28$ and $1.1 \mathrm{kgm}^{-3}$ for $S_{1}, S_{2}, S_{3}$ and $S_{4}$ salinity levels, respectively. The water productivity of HD 2894 cultivar for rabi 2011-12 treated with foliar potassium was found to be $1.78,1.6,1.23$ and $0.82 \mathrm{kgm}^{-3}$ at $\mathrm{S}_{1}, \mathrm{~S}_{2}, \mathrm{~S}_{3}$ and $\mathrm{S}_{4}$ salinity levels, respectively. The water productivity of same cultivar without foliar application of potassium fertilizer was observed to be $1.7,1.49,1.07$ and $0.79 \mathrm{kgm}^{-3}$ for $\mathrm{S}_{1}, \mathrm{~S}_{2}, \mathrm{~S}_{3}$ and $\mathrm{S}_{4}$ salinity levels, respectively (Fig. 4). Overall, the KRL-1-4 cultivar under foliar treatment resulted in increase in water productivity by 6.3 to $21.1 \%$ as compared to the non-foliar treatments with irrigation water salinity ranging from 1.7 to $12 \mathrm{dSm}^{-1}$. The increase in water productivity of wheat with foliar potassium fertigation over the non-foliar application for the HD 2894 cultivar was found to vary from 3.8 to $14.9 \%$ with irrigation water salinity upto $12 \mathrm{dSm}^{-1}$.

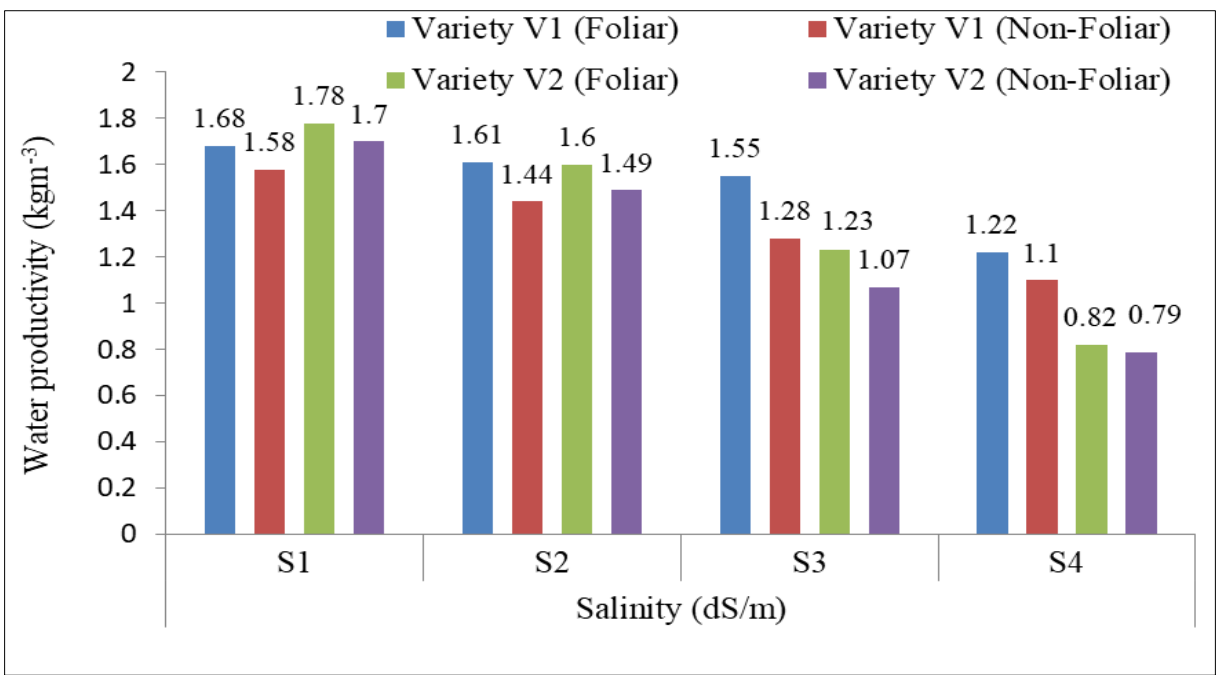

Fig 4: Water productivity of wheat cultivars with and without foliar potassium fertigation under irrigated saline regimes during Rabi 2011-2012

Moreover, under the same treatment combinations, the water productivity of both cultivars under irrigated saline regimes for Rabi 2012-13 are presented in Fig. 5. It was observed from Fig. 5 that the water productivity of KRL-1-4 treated with foliar potassium fertigation was found to be 1.81, 1.76, 1.57 and $1.11 \mathrm{kgm}^{-3}$ at $1.7,4,8,12 \mathrm{dSm}^{-1}$, respectively. The water productivity of the same cultivar without foliar potassium application was found to be $1.73,1.58,1.31$ and
$1.02 \mathrm{kgm}^{-3}$ at $\mathrm{S}_{1}, \mathrm{~S}_{2}, \mathrm{~S}_{3}$ and $\mathrm{S}_{4}$ salinity levels, respectively. The water productivity of HD-2894 treated with foliar potassium was $1.86,1.75,1.27$ and $0.74 \mathrm{kgm}^{-3}$ at $\mathrm{S}_{1}, \mathrm{~S}_{2}, \mathrm{~S}_{3}$ and $\mathrm{S}_{4}$ salinity levels, respectively. The water productivity of the same cultivar without foliar spray was observed to be $1.82,1.61,1.11$ and $0.69 \mathrm{kgm}^{-3}$ at $\mathrm{S}_{1}, \mathrm{~S}_{2}, \mathrm{~S}_{3}$ and $\mathrm{S}_{4}$ salinity levels, respectively (Fig. 5). 


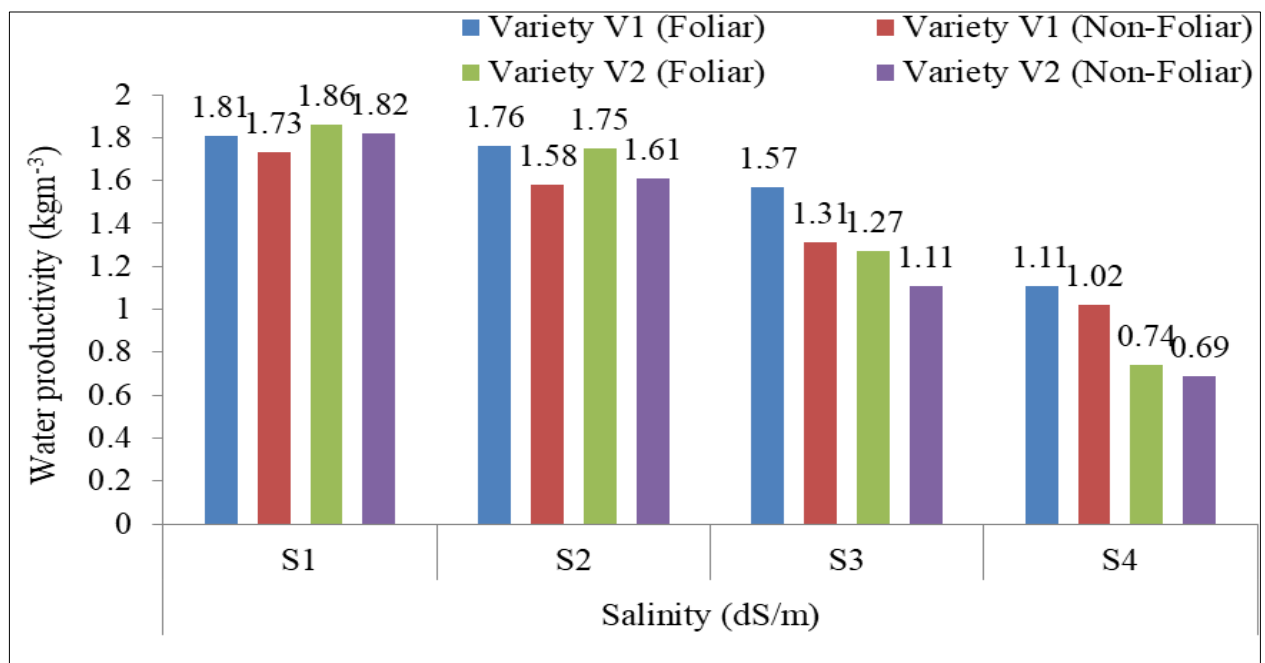

Fig 5: Water productivity of wheat cultivars with and without foliar potassium fertigation under irrigated saline regimes during Rabi 2012-2013

Overall, it was observed that the water productivity of both cultivars under foliar potassium fertigation resulted in higher water productivity for all salinity regimes as compared to the non-foliar treatment.

\section{Conclusions}

Water Productivity in regions with higher ground water salinity could be enhanced by cultivation of salt tolerant cultivar (KRL-1-4) and treated with potassium foliar fertigation at the heading stage in the ratio of $\left(\mathrm{K}^{+}: \mathrm{Na}^{+}:: 1: 10\right)$ at different salinity levels. There are regions with saline ground water as the only source of water for irrigation, farmers of the region have no option but to use saline water in crop cultivation. The developed strategy could be used to enhance the water productivity and yield of wheat crop grown under such regions.

\section{References}

1. Adiloglu S, Adiloglu A, Ozkil M. Effects of different levels of $\mathrm{NaCl}$ and $\mathrm{KCl}$ on growth and some biological indexes of wheat plant. Pakistan Journal of Biological Sciences. 2007; 10(11):1941-1943.

2. Baque A, Karim A, Hamid A, Tetsushi H. Effects of fertilizer potassium on growth, yield and nutrient uptake of wheat (Triticum aestivum) under water stress conditions. South Pacific Studies. 2006; 27(1): 25-35.

3. Ghassemi F, Jakeman AJ, Nix HA. Salinisation of land and water resources: Human causes, extent, management and case studied. UNSW Press, Sydney, Australia, and CAB International, Wallingford, UK, 1995.

4. Jabeen N, Ahmad R. Improving tolerance of sunflower and safflower during growth stages to salinity through foliar spray of nutrient solutions. Pakistan Journal of Botany. 2012; 44(2):563-572.

5. Kumar M, Sarangi A, Singh DK, Rao AR, Sudhishri S. Response of wheat cultivars to foliar potassium fertilization under irrigated saline environment. Journal of Applied and Natural Sciences. 2016; 8(1):429-436.

6. Mesbah EAE. Effect of irrigation regimes and foliar spraying of potassium on yield, yield component and water use efficiency of wheat (Triticum aestivum L.) in sandy soils. World Journal of Agricultural Sciences. 2009; 5(6):662-669.

7. Raza MAS, Saleem MF, Shah GM, Jamil M, Khan IH. Potassium applied under drought improves physiological and nutrient uptake performances of wheat (Triticum aestivun L.). Journal of Soil Science and Plant Nutrition. 2013; 13(1):175-185.

8. Russo MA, Belligno A, Sardo V. Wheat Response to a Soil Previously Irrigated with Saline Water. Italian Journal of Agronomy. 2009; 4:121-125.

9. Zheng Y, Jia A, Ning T, Xu J, Li Z, Jiang G. Potassium nitrate application alleviates sodium chloride stress in winter wheat cultivars differing in salt tolerance. Journal of Plant Physiology. 2008; 165:1455-1465.

10. Zheng Y, Xu X, Simmons M, Zhang C, Gao F and Li Z. Responses of physiological parameters, grain yield, and grain quality to foliar application of potassium nitrate in two contrasting winter wheat cultivars under salinity stress. Journal of Plant Nutrition and Soil Science. 2010; 173:444-452. 